\title{
Effects of nitrogen source on the physiology and metal nutrition of Emiliania huxleyi grown under different iron and light conditions
}

\author{
Deborah L. Muggli*, Paul J. Harrison \\ Department of Oceanography, 6270 University Blvd, University of British Columbia, Vancouver, British Columbia, \\ Canada V6T $1 \mathrm{Z4}$
}

\begin{abstract}
Emiliania huxleyi, a small oceanic coccolithophore, was isolated from the NE subarctic Pacific and maintained under oceanic conditions. Coccolith-forming cultures were grown with either $\mathrm{NO}_{3}{ }^{-}$or $\mathrm{NH}_{4}{ }^{+}$as the primary nitrogen source. Fe-stress was induced experimentally, and physiological parameters including metal quotas ( $\mathrm{Fe}, \mathrm{Mn}, \mathrm{Zn}, \mathrm{Cu}$ ) were measured for both $\mathrm{NO}_{3}{ }^{-}$- and $\mathrm{NH}_{4}{ }^{+}$-grown cells to determine whether it was advantageous for the cells to grow on $\mathrm{NH}_{4}{ }^{+}$rather than $\mathrm{NO}_{3}{ }^{-}$under Fe-stressed conditions. The parameters used to observe the cell's physiological status were specific growth rate $(\mu)$, cell volume (CV), carbon (C), chlorophyll a (chl a), and nitrogen (N) per cell volume. Under Fe-replete conditions ( $100 \mathrm{nM} \mathrm{Fe}$ ), no physiological parameters were significantly different $(\mathrm{p}<$ $0.05)$ between $\mathrm{NO}_{3}{ }^{-}$- and $\mathrm{NH}_{4}{ }^{+}$-grown cells. However, under Fe-stressed conditions, $\mathrm{CV}\left(\mathrm{NH}_{4}{ }^{+}>\mathrm{NO}_{3}{ }^{-}\right.$), chl a CV${ }^{-1}\left(\mathrm{NH}_{4}{ }^{+}<\mathrm{NO}_{3}{ }^{-}\right), \mathrm{MnCV}^{-1}\left(\mathrm{NH}_{4}{ }^{+}<\mathrm{NO}_{3}\right)$, and $\mathrm{Mn}: \mathrm{C}\left(\mathrm{NH}_{4}{ }^{+}<\mathrm{NO}_{3}{ }^{-}\right)$were all significantly different $(\mathrm{p}<0.05)$ for $\mathrm{NO}_{3}{ }^{-}$- and $\mathrm{NH}_{4}{ }^{+}$-grown cells. Under Fe-stressed conditions, $\mathrm{NO}_{3}{ }^{-}$-grown cells of $E$. huxleyi maintained the same or greater levels of chl $a_{1} \mathrm{~N}, \mathrm{Fe}, \mathrm{Mn}$, and $\mathrm{Cu}$ as $\mathrm{NH}_{4}{ }^{+}$-grown cells, largely due to the drastic decrease in $\mathrm{CV}$ of $\mathrm{NO}_{3}{ }^{-}$-grown cells under Fe-stress. Although $\mathrm{NO}_{3}{ }^{-}$-grown cells substantially decreased their $\mathrm{CVs}$ under Fe-stressed conditions (whereas $\mathrm{NH}_{4}{ }^{+}$-grown cells did not), both $\mathrm{NO}_{3}{ }^{-}$- and $\mathrm{NH}_{4}{ }^{+}$-grown cells reduced their $\mathrm{CVs}$ equally under limiting-irradiance, Fe-replete conditions. A reduction in $\mathrm{CV}$ by the $\mathrm{NO}_{3}{ }^{-}$-grown cells is particularly advantageous for cells living in a low Fe environment, since it reduces the cellular requirements for photosynthate, $\mathrm{N}$, and $\mathrm{Fe}$. The fact that these already small cells become smaller, along with their unique ability to maintain chlorophyll synthesis at $\mathrm{Fe}$ levels limiting to cell division, may help explain why $E$. huxleyi is a member of the numerically dominant size class in the NE subarctic Pacific.
\end{abstract}

KEY WORDS: Nitrogen · Ammonium - Nitrate · Coccolithophore · Emiliania huxleyi · Iron Iron limitation - Metal quotas · Oceanic S Subarctic Pacific

\section{INTRODUCTION}

The Subarctic Pacific Ocean is one of the HNLC (high nutrient-low chlorophyll) regions of the world's ocean where high macronutrients (N, P, Si) and low chlorophyll concentrations are found year round. Fe is present in extremely low concentrations $(<0.05 \mathrm{nmol}$ $\mathrm{kg}^{-1}$ seawater) and thought to limit phytoplankton growth rates (Martin et al. 1989) as well as controlling species composition in combination with grazing

\footnotetext{
•E-mail: muggli@unixg.ubc.ca
}

(Miller et al. 1991, P. Boyd et al. unpubl.). The region is dominated by small-sized phytoplankton species (non-diatoms), with large diatoms being present but not numerically abundant (Booth et al. 1982, Booth 1988, P. Boyd et al. unpubl.). One of the determining factors theorized to influence the species composition of phytoplankton in HNLC regions in general is the nitrogen source that phytoplankton use for their growth (Bruland et al. 1991, Morel et al. 1991, Price et al. 1991, 1994). This hypothesis is based on the theoretical calculations (Raven 1988) that nitrate utilization requires more Fe compared to ammonium utilization. 
Nitrate and nitrite reductase catalyze the reduction of nitrate to nitrite, and nitrite to ammonium, respectively. Both enzymes contain $\mathrm{Fe}$, in a cytochrome molecule in the former, and in an Fe porphyrin molecule as well as ferredoxin in the latter (Goodwin \& Mercer 1983). As a result, cells utilizing nitrate should theoretically have a higher $\mathrm{Fe}$ requirement than cells utilizing ammonium, and the difference has been calculated by Raven (1988) to result in a $60 \%$ higher $\mathrm{Fe}$ requirement for cells grown on nitrate compared to ammonium to achieve the same growth rates.

In addition, theoretically a cell must expend more reductant to grow on nitrate than on ammonium, because nitrate must be reduced to first nitrite and then to ammonium before it can be incorporated into amino acids. It has been calculated that due to the extra reducing steps required for nitrate incorporation, cells growing on nitrate require $22 \%$ more reductant than cells growing on ammonium (Thompson et al. 1989). In addition, it has been suggested that the energetic cost for the actual transport of nitrate across the cell membrane is higher than that for ammonium (Falkowski 1975, Turpin \& Bruce 1990). Therefore, regardless of the $\mathrm{Fe}$ conditions, cells utilizing ammonium should have a theoretical advantage based on energy considerations over cells utilizing nitrate.

$\mathrm{Fe}$ is also required for chlorophyll synthesis (Spiller et al. 1982) and is a component of cytochrome and ferredoxin molecules, which are involved in electron transport for both photosynthesis and respiratory processes (Terry 1980, 1983, Sandmann 1985). Hence, a cell that is Fe-stressed could be analogous to one that is 'energy'-stressed, such as a light-limited cell. As a result, under light limitation, cells utilizing nitrate may not have as much energy to expend on other functions, perhaps resulting in lower growth rates or $\mathrm{N}$ quotas of nitrate-grown cells compared to ammonium-grown cells. Similarly, under Fe-stressed conditions, nitrate uptake could be more adversely affected than ammonium uptake due to the higher energy costs, resulting in nitrate-grown cells not being able to maintain their normal $\mathrm{N}$ quotas. In addition to $\mathrm{Fe}, \mathrm{Mn}$, $\mathrm{Zn}$ and $\mathrm{Cu}$ are also essential trace metals for phytoplankton metabolism and are involved in primary metabolic functions such as photosynthesis, respiration, $\mathrm{N}$ metabolism, and detoxification processes (Sandmann \& Boger 1983, Sunda 1988/1989).

We present here experiments conducted with an oceanic coccolithophore, Emiliania huxleyi, isolated from the NE subarctic Pacific. E. huxleyi is a small (<5 $\mu$ m diameter), ubiquitous oceanic coccolithophore occurring in almost all of the world's ocean except polar waters. Most noted are the very large blooms of this calcifying organism in the North Atlantic, span- ning areas of $250000 \mathrm{~km}^{2}$ or more (Holligan et al. 1993). This organism is receiving worldwide attention as a potential carbon sink due to its coccolith production and loss, as well as its influence on global climate via dimethylsulfoniopropionate (DMSP) production and carbon sequestration (Keller et al. 1989, Flynn 1990). In the North Pacific, large blooms of this species (or any other phytoplankter) do not occur, but E. huxleyi is a member of the most abundant size class present (Booth et al. 1982, Taylor \& Waters 1982). In addition, cells $<5.0 \mu \mathrm{m}$ in diameter are responsible for $2 / 3$ of the phytoplankton carbon biomass at Station Papa (Stn P), with E. huxleyi belonging in this size class (Booth 1988). E. huxleyi is also the most abundant coccolithophore found at Stn P (Honjo \& Okada 1974). The important environmental parameters regulating phytoplankton growth rates in the North Atlantic include nitrogen and light, whereas in the subarctic Pacific, Fe must also be considered.

This is the first report on physiological, biochemical, and metal composition parameters obtained from an oceanic coccolithophore isolated from the NE subarctic Pacific. We examine both the effects of $N$ source and $\mathrm{Fe}$ condition on the physiological status of Emiliania huxleyi in an attempt to determine whether it is advantageous for this organism to utilize ammonium rather than nitrate under low Fe conditions. Experiments are also presented on the effects of irradiance on both nitrate-and ammonium-grown cells, since under low irradiance levels competition for photosynthetically derived energy may become crucial, similar to Festressed conditions. Metal quotas were measured using non-radiotracer ('cold-metal'), trace-metal clean techniques, allowing for the simultaneous measurement of multiple metals. $\mathrm{Mn}, \mathrm{Zn}$, and $\mathrm{Cu}$ were measured along with Fe to determine if their cellular levels varied with intracellular Fe levels, perhaps indicating additional utilization of these metals under Fe-stress. The physiological parameters measured were growth rate, CV, chlorophyll a (chl a) quota, in vivo fluorescence per chl a, N quota, and C quota.

\section{MATERIALS AND METHODS}

Emiliania huxleyi was isolated in November 1991 from the NE subarctic Pacific (Stn P, $145^{\circ} \mathrm{W}, 50^{\circ} \mathrm{N}$ ). Cultures were maintained in natural Stn $\mathrm{P}$ water to retain the organism's ability to form coccoliths. Laboratory data were acquired shortly after isolation, with these particular experiments being conducted approximately 1 yr after isolation.

Experiments were carried out using Chelex-treated Aquil synthetic ocean water, SOW (Price et al. 1988/ 1989), made up with Nanopure water (Barnstead 
Nanopure II distilled-deionized water system) and a.s.c. certified salts. The Chelex 100 resin was prepared according to Price et al. (1988/1989), with the exception of using Ultra $\mathrm{HCl}$ (Seastar Chemicals) for the final $\mathrm{HCl}$ soak. The total Fe remaining in the SOW after it was passed through the Chelex column at a rate of $<1 \mathrm{ml} \mathrm{min}^{-1}$ was $<0.8 \mathrm{nmol} \mathrm{kg}{ }^{-1}$, following the procedure of Yang (1993). Due to a limited supply of natural Stn P water, artificial seawater was chosen for these particular experiments.

The SOW was microwave-sterilized in acid-cleaned 21 Teflon ${ }^{\otimes}$ bottles for a total of 12 min (Keller et al. 1988). All handling of the medium was done in a class 100 laminar flowhood to prevent metal contamination and contamination by bacteria. Macronutrient stocks were made up in Nanopure water and Chelex-treated at $\mathrm{pH} 3.0$ for near $100 \%$ Fe removal ( $\mathrm{R}$. Chretien unpubl. data). Macronutrients were added to achieve a final concentration of $30 \mu \mathrm{M}$ of either nitrate or ammonium, and 5.0 $\mathrm{MM}$ phosphate. This level of ammonium addition had no detrimental effect on the organism's growth rate or overall appearance. EDTA was added to yield a final concentration of $10 \mu \mathrm{M}$. Metal stocks were prepared in $0.01 \mathrm{M}$ Ultra $\mathrm{HCl}$ in Nanopure water. Final metal concentrations added were: $8.0 \mathrm{nM} \mathrm{Zn,} 23 \mathrm{nM}$ $\mathrm{Mn}, 1.0 \mathrm{nM} \mathrm{Cu}, 2.5 \mathrm{nM} \mathrm{Co}, 100 \mathrm{nM} \mathrm{Mo}$, and $10 \mathrm{nM} \mathrm{Se}$. $100 \mathrm{nM}$ Fe final concentration was added for the Fereplete cultures, and no $F e$ was added for the other treatments. Thiamine and biotin were added to give a final concentration of $1 \times 10^{-4} \mathrm{~g} \mathrm{l}^{-1}$ and $5 \times 10^{-7} \mathrm{~g} \mathrm{l}^{-1}$, respectively.

Fe experiments. Fe-replete experiments: Semicontinuous cultures were grown in quadruplicate with either nitrate or ammonium as the $N$ source in acidcleaned 2.81 polycarbonate Fernbach flasks. All plastics coming in contact with the medium or cultures were acid-cleaned in the following manner: an organic wash with Sparkleen detergent or acetone, a soak in $3 \mathrm{~N}$ reagent grade $\mathrm{HCl}$ for at least $24 \mathrm{~h}, 2$ rinses with Nanopure water, and a final soak in $0.01 \mathrm{M}$ Ultra $\mathrm{HCl}$ in Nanopure water for at least $1 \mathrm{wk}$. The flasks were equipped with Teflon ${ }^{\circledR}$ tubes and silicone stoppers. Cultures were not mechanically stirred, as this knocked off many of the coccoliths, but they were mixed once a day by swirling the flasks by hand. Cultures were maintained at $16^{\circ} \mathrm{C}$ on a 14 h light: $10 \mathrm{~h}$ dark cycle with Vitalite fluorescent lights. The irradiance, as measured by a Biospherical Instruments model QSL100 sensor, was $150 \mu \mathrm{E} \mathrm{m}^{-2} \mathrm{~s}^{-1}$ which was saturating for growth. Cultures were grown for 10 generations and harvested in log phase.

Fe-stressed experiments: Cultures were grown in triplicate with either nitrate or ammonium as the nitrogen source in identical conditions as above. However, when Emiliania huxleyi was semi-continuously diluted with 'no Fe' medium ( $\left.<0.8 \mathrm{nmol} \mathrm{kg}{ }^{-1}\right)$, no physiological evidence of Fe limitation was observed. Therefore, we devised a culture protocol that resulted in Fe-limited cells after several transfers, similar to procedures used when comparing macronutrient deplete vs replete cells. Cultures were grown semi-continuously and sampled after $9 \mathrm{~d}$ ( 3 dilutions). These cells were in medium $<0.8 \mathrm{nmol} \mathrm{Fe} \mathrm{kg}^{-1}$ with $10 \mu \mathrm{M}$ EDTA, but they showed little or no signs of Fe-stress (no drastic decrease in growth rate). Cells from these same cultures were again diluted and allowed to grow up until early stationary phase was reached as determined by cell counts. At this time, all macro-and micronutrients except Fe were added directly to the culture flasks (no new medium was added), forcing the cell number to increase with minimal additions of Fe to the medium (via contamination). This was repeated until the addition of macronutrients caused no increase in cell numbers ( 2 additions with macro- and micromutrients, 1 addition with $\mathrm{N}$ and $\mathrm{P}$ only). These 'Fe-stressed' cultures represent cells whose cell division was halted due to Fe limitation. After sampling, a final concentration of $5 \mathrm{nM}$ Fe was added to the cultures and cell division resumed. The final cell densities of the Fe-stressed cultures were ca $6 \times 10^{5}$ cells $\mathrm{ml}^{-1}$.

Growth rates were calculated from linear regressions of plots of the natural log of cell number vs time. Cell numbers and cell volumes were measured on a Coulter Counter model TAII. The pH was decreased to 5 with $\mathrm{HCl}$ before counting to dissolve the coccoliths and prevent interference, as the coccoliths overlapped with some of the same channels as the cell counts. The $\mathrm{HCl}$ was added directly to the counting chambers, allowed to sit for 1 min to completely dissolve coccoliths (time series were conducted), and then counted on the Coulter Counter. Chlorophyll a concentrations were determined by in vitro fluorometry (extracted in $90 \%$ ethanol; sonicated for $10 \mathrm{~min}$; refrigerated for $24 \mathrm{~h}$; fluorescence measured on a Turner Designs Fluorometer model 10-AU before and after acidification). The fluorometer was calibrated with chl a standards (Parsons et al. 1984).

Samples for particulate organic carbon and nitrogen were collected on precombusted $13 \mu \mathrm{m}$ Gelman A/E filters and analyzed on a Carlo Erba CHN analyzer. Samples with and without coccoliths were measured. The $\mathrm{C}$ content of cells minus their coccoliths was determined by dissolving the coccoliths with $\mathrm{HCl}(\mathrm{pH} 5)$ and filtering. This procedure did not appear to lyse the cells, as the $\mathrm{N}$ per cell remained the same for both nonacidified and acidified samples.

Metal quotas (Fe, Mn, $\mathrm{Zn}, \mathrm{Cu}$ ) were measured using non-radiotracer (cold-metal), trace-metal clean techniques. For the Fe-replete experiment, cultures were filtered onto acid-cleaned $3.0 \mu \mathrm{m}$ pore size cellu- 
lose acetate filters using acid-cleaned Nalgene filtration holders. Acid-cleaned cellulose acetate filters gave similar blanks to acid-cleaned polycarbonate filters, and were used instead of polycarbonate filters for their ease in digestion. For total (intra- plus extracellular) $\mathrm{Fe}$ measurements, filters were rinsed twice with $5 \mathrm{ml}$ of Chelex-treated Stn P water to wash off any loosely associated metals. Filters were carefully removed, placed in acid-cleaned locking petri dishes and frozen. The filters were then digested in concentrated Ultra $\mathrm{HNO}_{3}^{-}$(Seastar Chemicals) using a CEM Corporation microwave digestion apparatus. The digestate was completely clear. A subsample was taken and diluted appropriately for injection into a Varian graphite furnace atomic absorption spectrometer with Zeeman background correction. A minimum of 3 filter blanks for all treatments were taken and subtracted from the samples. Internal or intracellular Fe, $\mathrm{Fe}_{\text {int, }}$ was determined by Ti(III) treatment (Hudson \& Morel 1989). Cultures were first treated with Ultra $\mathrm{HCl}$ to remove the coccoliths prior to Ti(III) treatment. This was to avoid any complications involving adsorption of $\mathrm{Fe}$ onto the coccoliths and to eliminate the extra barrier to the cell membrane. The acid and Ti(III) treatment did not increase the cellulose acetate filter blanks. Acid treated, Ti(III) washed filter blanks were subtracted from the identically treated culture samples. However, even though the acid and Ti(III) treatment did not increase the filter blanks, the treatment did cause an increase in the Fe retained on the filters for culture samples of Fe-stressed cells. We can think of 3 possible reasons for this increase: (1) Any contaminating $\mathrm{Fe}$ present in the Ti(III) reagent could have bound to empty Fe-uptake sites on the cell surface of the Festressed cells; (2) the extra particulate matter present on culture samples prevented complete rinsing with the Chelex-treated Stn P water; or (3) Fe-stressed cells may be producing organic compounds, possibly to aid in $\mathrm{Fe}$ acquisition and transport, which may cause retention of $\mathrm{Fe}$ on the filters. Due to these complications at low particulate $\mathrm{Fe}$ concentrations (Fe-stressed cells), we estimated the $\mathrm{Fe}_{\text {int }}$ using Hudson \& Morel's (1990) finding that 75 to $90 \%$ of the total $\mathrm{Fe}$ in Festressed diatom cultures was intracellular. Furthermore, at external Fe concentrations below $100 \mathrm{nM}$, the Ti(III) treatment does not appear to be necessary, as it was found to not remove any extracellular Fe at very low external Fe concentrations (Sunda et al. 1991)

All statistical comparisons were done using a Student's t-test at the $95 \%$ confidence level $(p<0.05)$. Comparisons were made between ammonium and nitrate-grown cultures for a given Fe treatment.

Irradiance experiments. Cultures were grown in triplicate in Silinized-treated (Pierce) $50 \mathrm{ml}$ glass tubes with either $30 \mu \mathrm{M}$ nitrate or ammonium as the $\mathrm{N}$ source.
Medium preparation and additions were identical to the Fe-replete experiments (100 nM Fe, $10 \mu \mathrm{M}$ EDTA). Cultures were maintained in quasi-steady state (diluted at $1 / 3$ of the maximal fluorescence) for a minimum of 6 generations using Vitalite tubes as the irradiance source, at irradiances of $24,40,70,119$, and $176 \mu \mathrm{E} \mathrm{m}^{-2}$ $\mathrm{s}^{-1}$. Growth rates were obtained by regressions of the natural $\log$ of in vivo fluorescence versus time. All other methods were the same as for the Fe experiments.

\section{RESULTS}

\section{Fe experiments}

Growth rate

The specific growth rates of nitrate- and ammoniumgrown cells were not significantly different under the high Fe (100 nM Fe) treatment (Table 1). Under the low $\mathrm{Fe}(0.8 \mathrm{nM} \mathrm{Fe})$ treatment, nitrate-grown cells grew significantly faster than ammonium-grown cells (Table 1). For the Fe-stressed cultures, cell numbers were increased until the external Fe concentration reached levels limiting to growth, resulting in no cell division. After sampling, a final concentration of $5 \mathrm{nM}$ Fe was added to the cultures, and cell division resumed at a growth rate of 0.0128 and $0.0095 \mathrm{~h}^{-1}$ measured over a $2 \mathrm{~d}$ period for ammonium and nitrate-grown cultures, respectively (Table 1). Ammonium-grown cells grew significantly faster than nitrate-grown cells after this $\mathrm{Fe}$ addition.

\section{Cell volume}

The cell volume, $\mathrm{CV}$, of nitrate and ammoniumgrown cells was not statistically different under the high and low Fe treatments (Fig. 1, Table 1). However, nitrate-grown cells had significantly smaller CVs than ammonium-grown cells under Fe-stressed conditions ( $\mathrm{p}=0.007$ ), with the mean CVs being 24.9 and $33.8 \mathrm{\mu m}^{3}$, respectively. In general, the $\mathrm{CV}$ of both nitrate- and ammonium-grown cells were larger under the high Fe treatment than under the low Fe treatment (Fig. 1). However, the CV of ammonium-grown cells between the low $\mathrm{Fe}$ and Fe-stressed treatments remained identical, whereas the $\mathrm{CV}$ of nitrate-grown cells decreased 30\% under Fe-stress (Fig. 1, Table 1).

\section{Biochemical composition}

Chlorophyll a. Chl a cell-1 was not statistically different for nitrate- and ammonium-grown cells under the 
Table 1. Emiliania huxleyi. Physiological parameters for nitrate- and ammonium-grown cultures under 3 Fe treatments: high Fe (100 nM Fe), low Fe (0.8 nM Fe), and Fe-stressed conditions ( $\ll 0.8 \mathrm{nM} \mathrm{Fe}$ ). Values are means $\pm 1 \mathrm{SE}$ ( $\mathrm{n}=4$ for $100 \mathrm{nM} F \mathrm{Fe}, \mathrm{n}=3$ for other Fe treatments). "Significant difference at $\mathrm{p}<0.05$ between $\mathrm{NO}_{3}{ }^{-}$- and $\mathrm{NH}_{4}{ }^{+}$-grown cells for a particular Fe treatment with the asterisk placed next to the greater value $\mu$ : growth rate; $\mathrm{CV}$ : cell volume; $\mathrm{C}_{1}$ : total cell carbon, including coccoliths; $\mathrm{C}_{\mathrm{a}}$ : cell carbon excluding coccoliths (coccoliths removed by acidification, see 'Methods'); Fl: fluorescence

\begin{tabular}{|c|c|c|c|c|c|c|}
\hline \multirow[t]{2}{*}{ Parameters } & \multicolumn{2}{|c|}{ High Fe (100 nM) } & \multicolumn{2}{|c|}{ Low Fe $\{0.8 \mathrm{nM}\}$} & \multicolumn{2}{|c|}{ Fe-stressed $(\ll 0.8 \mathrm{nM})$} \\
\hline & $\mathrm{NH}_{4}^{+}$ & $\mathrm{NO}_{3}^{-}$ & $\mathrm{NH}_{4}^{+}$ & $\mathrm{NO}_{3}^{-}$ & $\mathrm{NH}_{4}{ }^{+}$ & $\mathrm{NO}_{3}^{-}$ \\
\hline \multirow[t]{2}{*}{$\mu\left(h^{-1}\right)$} & $\begin{array}{c}0.0175 \\
\pm 0.0010\end{array}$ & $\begin{array}{c}0.0183 \\
\pm 0.0010\end{array}$ & $\begin{array}{c}0.0134 \\
\pm 0.0002\end{array}$ & $\begin{array}{l}0.0191^{\circ} \\
\pm 0.0010\end{array}$ & 0 & 0 \\
\hline & & & & & $\begin{array}{c}{[0.0128]^{*},} \\
\pm 0.0006\end{array}$ & $\begin{array}{l}{[0.0095]^{\mathrm{a}}} \\
\pm 0.0007\end{array}$ \\
\hline$C V\left(\mu m^{-3}\right)$ & $53.0 \pm 1.6$ & $48.9 \pm 2.5$ & $36.6 \pm 0.6$ & $34.9 \pm 0.7$ & $33.8^{\circ} \pm 1.5$ & $24.9 \pm 0.9$ \\
\hline Chl a cell ${ }^{-1}\left(\mathrm{fg} \mathrm{cell}^{-1}\right)$ & $120 \pm 8$ & $120 \pm 3$ & $110 \pm 6$ & $110 \pm 13$ & $130^{\circ} \pm 3$ & $110 \pm 4$ \\
\hline Chl $a C^{-1}\left(\mathrm{fg} \mu \mathrm{m}^{-3}\right)$ & $2.2 \pm 0.2$ & $2.5 \pm 1.0$ & $3.1 \pm 0.3$ & $3.2 \pm 0.3$ & $4.0 \pm 0.2$ & $4.5^{*} \pm 0.2$ \\
\hline $\mathrm{N}$ cell ${ }^{-1}\left(\mathrm{pg}\right.$ cell $\left.^{-1}\right)$ & $1.9 \pm 0.1$ & $1.8 \pm 0.1$ & $1.4 \pm 0.2$ & $1.5 \pm 0.1$ & $1.6^{\cdot} \pm 0.1$ & $1.3 \pm 0.1$ \\
\hline $\mathrm{NCV}^{-1}\left(\mathrm{fg} \mu \mathrm{m}^{-3}\right)$ & $36 \pm 2$ & $37 \pm 1$ & $38 \pm 6$ & $43 \pm 1$ & $47 \pm 2$ & $52 \pm 4$ \\
\hline$C_{t} \operatorname{cell}^{-1}(\mathrm{pg}$ cell-1) & $31.9^{\circ} \pm 0.8$ & $27.6 \pm 1.1$ & $25.2 \pm 6.2$ & $21.2 \pm 3.4$ & $28.3^{\circ} \pm 1.3$ & $13.4 \pm 0.1$ \\
\hline$C_{t} C V^{-1}\left(p g \mu m^{-3}\right)$ & $0.60 \pm 0.01$ & $0.56 \pm 0.02$ & $0.69 \pm 0.17$ & $0.61 \pm 0.09$ & $0.84^{*} \pm 0.02$ & $0.52 \pm 0.02$ \\
\hline $\mathrm{C}_{\mathrm{a}} \operatorname{cell}^{-1}\left(\right.$ pg cell $\left.{ }^{-1}\right)$ & $13.9 \pm 0.3$ & $13.9 \pm 0.9$ & $17.7 \pm 2.6$ & $16.5 \pm 1.8$ & $19.8^{*} \pm 1.1$ & $12.9 \pm 0.8$ \\
\hline $\mathrm{C}_{\mathrm{a}} \mathrm{CV}^{-1}\left(\mathrm{pg} \mu \mathrm{m}^{-3}\right)$ & $0.26 \pm 0.01$ & $0.28 \pm 0.03$ & $0.48 \pm 0.07$ & $0.47 \pm 0.04$ & $0.59 \pm 0.02$ & $0.53 \pm 0.01$ \\
\hline $\mathrm{C}_{\mathrm{a}}: \mathrm{N}(\mathrm{mol}: \mathrm{mol})$ & $8.3 \pm 0.3$ & $8.9 \pm 0.7$ & $14.1 \pm 0.5$ & $12.5 \pm 1.3$ & $14.0 \pm 0.8$ & $11.2 \pm 1.2$ \\
\hline In vivo Fl:chl a (ng chl $\left.a^{-1}\right)$ & $0.30 \pm 0.02$ & $0.28 \pm 0.01$ & $0.32 \pm 0.01$ & $0.35 \pm 0.03$ & $0.35 \pm 0.03$ & $0.36 \pm 0.01$ \\
\hline$C_{a}:$ chl $a(w t)$ & $120 \pm 9$ & $120 \pm 11$ & $160 \pm 46$ & $150 \pm 5$ & $150 \pm 11$ & $120 \pm 5$ \\
\hline
\end{tabular}

high or low Fe treatment, but it was significantly higher for ammonium-grown cells under Fe-stress (Table 1). However, when normalized to $\mathrm{CV}$, chl a $\mathrm{CV}^{-1}$, the chl a content was significantly higher for nitrate- than for ammonium-grown cells under Fe-stressed conditions (Fig. 2A, Table 1). There was no significant difference in chl a $\mathrm{CV}^{-1}$ between nitrate- and ammonium-grown cells under the other Fe conditions (Fig. 2A, Table 1). Because of the large difference in CV between nitrateand ammonium-grown Fe-stressed cells, all physiological parameters were normalized to $\mathrm{CV}$.

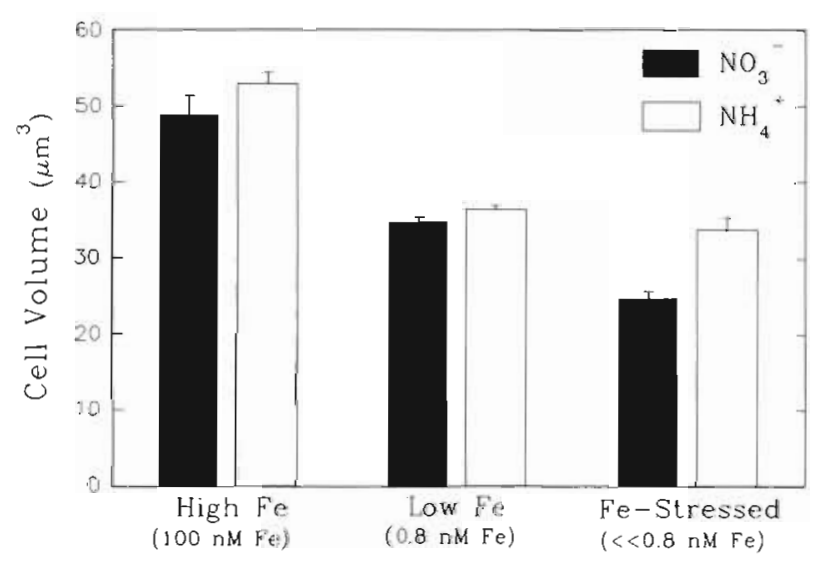

Fig. 1. Emiliania huxleyi. Cell volume vs Fe treatment for $\mathrm{NO}_{3}{ }^{-}-$and $\mathrm{NH}_{4}{ }^{-}$-grown cells. Error bars represent standard error ( $n=4$ for $100 \mathrm{nM} \mathrm{Fe}, n=3$ for other Fe treatments)
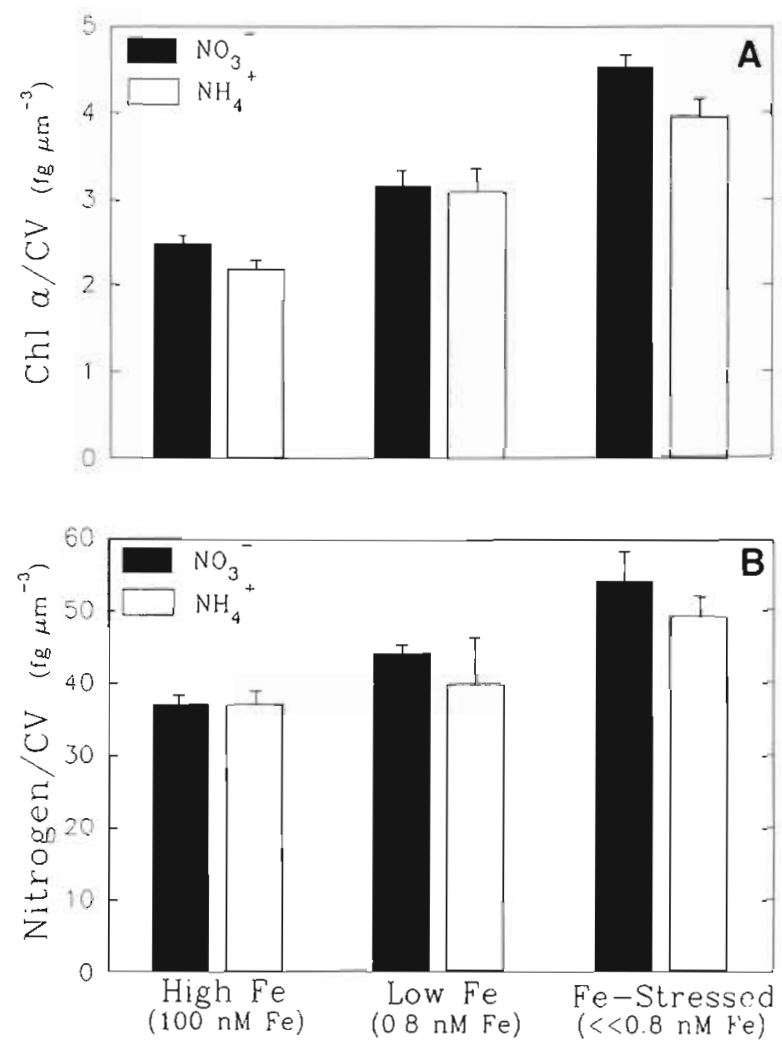

Fig. 2. Emiliania huxleyi. (A) Chlorophyll a per CV and (B) $\mathrm{N}$ per $\mathrm{CV}$ vs $\mathrm{Fe}$ treatment for $\mathrm{NO}_{3}{ }^{-}-$and $\mathrm{NH}_{4}{ }^{+}$-grown cells. (For error bars see Fig. 1) 
In vivo fluorescence: chl a. The in vivo Fl:chl a, a measure of the efficiency of photosynthetic electron transport, was not significantly different between nitrate- and ammonium-grown cells for any of the Fe treatments (Table 1).

Nitrogen. The $\mathrm{N} \mathrm{CV}^{-1}$ of nitrate- and ammoniumgrown cells was not significantly different under any of the $3 \mathrm{Fe}$ treatments, including the condition when Fe was limiting cell division (Fig. 2B, Table 1). In addition, cells under Fe-stress had higher $\mathrm{N} \mathrm{CV}^{-1}$ values than cells under the other Fe treatments (Fig. 2B, Table 1).

Carbon. The total carbon $\left(\mathrm{C}_{1}\right) \mathrm{CV}^{-1}$, which includes coccolith carbon, was not statistically different for nitrate- and ammonium-grown cells under the high and low Fe treatments (Table 1). Similarly, cellular $\mathrm{C}$ excluding coccolith carbon $\left(\mathrm{C}_{\mathrm{a}}\right) \mathrm{CV}^{-1}$ was not different for ammonium- and nitrate-grown cells under these $\mathrm{Fe}$ treatments. Moreover, the amount of coccolith carbon, estimated by subtracting $C_{a}$ from $C_{1}$ remained fairly constant regardless of nitrogen source or Fe treatment. The exception was nitrate-grown cells under Fe-stress. However, due to the very small size of these cells, some of the coccoliths could have been lost through the filter.

Carbon: chlorophyll a. The $\mathrm{C}_{\mathrm{a}}$ : chl a ratio was not statistically different for nitrate- and ammonium-grown cells under any of the Fe conditions (Table 1).

\section{Metal composition}

Iron. The intracellular $\mathrm{Fe}\left(\mathrm{Fe}_{\mathrm{int}}\right) \mathrm{CV}^{-1}$ was not significantly different between nitrate and ammonium-grown cells under any of the Fe treatments tested (Table 2). When $\mathrm{Fe}$ quotas were normalized to $\mathrm{C}, \mathrm{Fe}_{1 \mathrm{nt}}: \mathrm{C}_{\mathrm{t}}$ or $\mathrm{Fe}_{\text {int }}: \mathrm{C}_{a}$, there was still no significant difference between

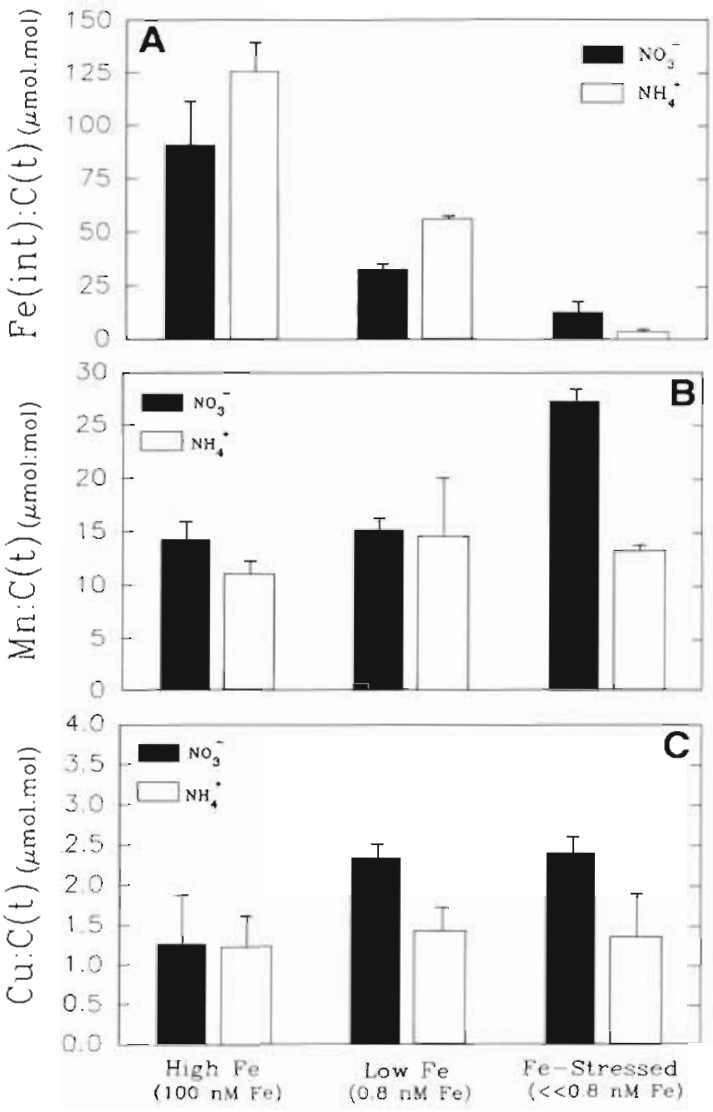

Fig. 3. Emiliania huxleyi. (A) Intracellular Fe per total $C_{1}(B)$ $\mathrm{Mn}$ per total $\mathrm{C}$, and (C) Cu per total carbon vs Fe treatment for $\mathrm{NO}_{3}{ }^{-}$- and $\mathrm{NH}_{4}{ }^{+}$-grown cells. (For error bars see Fig. 1)

nitrate- and ammonium-grown cells under the high $\mathrm{Fe}$ and the Fe-stressed treatments, but ammonium-grown cells had higher $\mathrm{Fe}_{i n t}: \mathrm{C}_{1}$ and $\mathrm{Fe}_{\mathrm{int}}: \mathrm{C}_{\mathrm{a}}$ than nitrate-grown cells under the low Fe treatment (Fig. 3A, Table 3).

Table 2. Emilianıa huxleyi. Metal quotas normalized per cell and per cell volume (CV) for nitrate- and ammonium-grown cultures under $3 \mathrm{Fe}$ treatments. $\mathrm{Fe}_{\mathrm{ml}}$ : intracellular $\mathrm{Fe}_{i} \mathrm{Fe}_{\mathrm{i}}$ : total $\mathrm{Fe}$ (both intra- and extracellular); amol $=1 \times 10^{-18}$ moles; $\mathrm{NA}$ : data not available. The $\mathrm{Fe}_{\mathrm{In}}$ values for the low $\mathrm{Fe}$ and Fe-stressed treatments are 75 to $90 \%$ of the measured $\mathrm{Fe}_{\mathrm{l}}$ (see 'Methods'). 'Significance as in Table 1

\begin{tabular}{|c|c|c|c|c|c|c|}
\hline \multirow[t]{2}{*}{ Parameters } & \multicolumn{2}{|c|}{ High Fe $(100 \mathrm{nM})$} & \multicolumn{2}{|c|}{ Low Fe $(0.8 \mathrm{nM})$} & \multicolumn{2}{|c|}{ Fe-stressed $(\ll 0.8 \mathrm{nM})$} \\
\hline & $\mathrm{NH}_{4}{ }^{+}$ & $\mathrm{NO}_{3}^{-}$ & $\mathrm{NH}_{4}{ }^{+}$ & $\mathrm{NO}_{3}^{-}$ & $\mathrm{NH}_{4}{ }^{+}$ & $\mathrm{NO}_{3}^{-}$ \\
\hline $\mathrm{Fe}_{\mathrm{nnt}} \mathrm{cell}^{-1}\left(\mathrm{amol} \mathrm{cell}^{-1}\right)$ & $330 \pm 38$ & $210 \pm 44$ & $\begin{aligned} & 94-110 \\
\pm & 26-32\end{aligned}$ & $\begin{array}{l}49-59 \\
\pm 4-5\end{array}$ & $9-11 \pm 3$ & $\begin{array}{l}14-17 \\
\pm 6-7\end{array}$ \\
\hline $\mathrm{Fe}_{\mathrm{int}} \mathrm{CV}^{-1}\left(\mathrm{amol} \mu \mathrm{m}^{-3}\right)$ & $6.3 \pm 0.6$ & $4.3 \pm 1.0$ & $\begin{array}{r}2.5-3.1 \\
\pm 0.7-0.8\end{array}$ & $\begin{array}{c}1.4-1.7 \\
\pm 0.08-0.09\end{array}$ & $\begin{array}{r}0.27-0.33 \\
\pm 0.07-0.08\end{array}$ & $\begin{array}{r}0.57-0.68 \\
\pm 0.02-0.03\end{array}$ \\
\hline Mncell ${ }^{-1}$ (amol cell $\left.{ }^{-1}\right)$ & $27 \pm 1$ & $30 \pm 1$ & $24 \pm 2$ & $24 \pm 1$ & $32 \pm 0.4$ & $31 \pm 1.2$ \\
\hline $\mathrm{MnCV}^{-1}\left(\mathrm{amol} \mu \mathrm{m}^{-3}\right)$ & $0.52 \pm 0.03$ & $0.61 \pm 0.05$ & $0.65 \pm 0.07$ & $0.69 \pm 0.03$ & $0.94 \pm 0.03$ & $1.2^{\bullet} \pm 0.1$ \\
\hline Zn cell ${ }^{-1}$ (amol cell $\left.{ }^{-1}\right)$ & $45 \pm 4$ & $41 \pm 5$ & NA & NA & $61 \pm 3$ & $15 \pm 1$ \\
\hline $\mathrm{ZnCV} \mathrm{CV}^{-1}\left(\mathrm{amol} \mu \mathrm{m}^{-3}\right)$ & $8.4 \pm 0.6$ & $8.3 \pm 0.1$ & NA & NA & $1.8 \pm 0.9$ & $0.6 \pm 0.04$ \\
\hline Cu cell ${ }^{-1}$ (amol cell $\left.{ }^{-1}\right)$ & $4.4 \pm 0.7$ & $2.8 \pm 1.2$ & $2.2 \pm 0.02$ & $3.6 \pm 0.80$ & $3.1 \pm 1.2$ & $2.7 \pm 0.3$ \\
\hline $\mathrm{CuCV} V^{-1}\left(\right.$ amol $\left.\mu \mathrm{m}^{-3}\right)$ & $0.08 \pm 0.01$ & $0.06 \pm 0.02$ & $0.06 \pm 0.01$ & $0.10^{\circ} \pm 0.02$ & $0.09 \pm 0.03$ & $0.11 \pm 0.01$ \\
\hline
\end{tabular}


Tabie 3. Emiliania huxleyi. Metal quotas normalized to cell carbon for nitrate- and ammonium-grown cultures under 3 Fe treatments. 'Significance as in Tables 1 \& 2

\begin{tabular}{|c|c|c|c|c|c|c|}
\hline \multirow{2}{*}{ Parameters } & \multicolumn{2}{|c|}{ High Fe $(100 \mathrm{nM})$} & \multicolumn{2}{|c|}{ Low $\mathrm{Fe}(0.8 \mathrm{nM})$} & \multicolumn{2}{|c|}{ Fe-stressed $(\ll 0.8 \mathrm{nM})$} \\
\hline & $\mathrm{NH}_{4}{ }^{+}$ & $\mathrm{NO}_{3}^{-}$ & $\mathrm{NH}_{4}^{+}$ & $\mathrm{NO}_{3}^{-}$ & $\mathrm{NH}_{4}^{+}$ & $\mathrm{NO}_{3}^{-}$ \\
\hline $\mathrm{Fe}_{\mathrm{in} !}: \mathrm{C}_{1}(\mu \mathrm{mol}: \mathrm{mol})$ & $130 \pm 14$ & $90 \pm 21$ & $\begin{array}{r}56-68 \\
+1.3-1.5\end{array}$ & $\begin{array}{r}33-40 \\
\pm 2.5-2.9\end{array}$ & $\begin{array}{r}3.9-4.7 \\
\pm 1.0-1.2\end{array}$ & $\begin{array}{r}12-15 \\
\pm 5.5-6.6\end{array}$ \\
\hline $\mathrm{Fe}_{\mathrm{n} n}: \mathrm{C}_{\mathrm{t}}(\mu \mathrm{mol}: \mathrm{mol})$ & $80 \pm 32$ & $160 \pm 54$ & $\begin{array}{r}66-80^{\circ} \\
\pm 2.3-2.8\end{array}$ & $\begin{array}{r}38-46 \\
\pm 3.6-4.3\end{array}$ & $\begin{array}{r}5.6-6.7 \\
\pm 1.4-1.7\end{array}$ & $\begin{array}{r}12-14 \\
\pm 5.2-6.2\end{array}$ \\
\hline $\mathrm{Mn}: \mathrm{C}_{1}$ ( $\left.\mu \mathrm{mol}: \mathrm{mol}\right)$ & $10 \pm 0.7$ & $13 \pm 0.8$ & $15 \pm 5.7$ & $15 \pm 1.1$ & $13 \pm 0.5$ & $27^{*} \pm 1.2$ \\
\hline $\mathrm{Mn}_{\mathrm{C}} \mathrm{C}_{\mathrm{d}}(\mu \mathrm{mol}: \mathrm{mol})$ & $25 \pm 2.5$ & $26 \pm 1.5$ & $17 \pm 3.3$ & $17 \pm 1.0$ & $19 \pm 0.9$ & $27^{\circ} \pm 2.3$ \\
\hline $\mathrm{Zn}: \mathrm{C}_{1}(\mu \mathrm{mol}: \mathrm{mol})$ & $17 \pm 1.5$ & $18 \pm 1.9$ & NA & NA & $26 \pm 14$ & $13 \pm 0.9$ \\
\hline $\mathrm{Zn}: \mathrm{C}_{\mathrm{a}}(\mu \mathrm{mol}: \mathrm{mol})$ & $41 \pm 7.2$ & $30 \pm 5.6$ & NA & NA & $38 \pm 21$ & $13 \pm 0.7$ \\
\hline $\mathrm{Cu} \mathrm{C}_{\imath}(\mu \mathrm{mol}: \mathrm{mol})$ & $1.2 \pm 0.4$ & $1.3 \pm 0.6$ & $1.4 \pm 0.3$ & $2.3 \pm 0.2$ & $1.4 \pm 0.6$ & $2.4 \pm 0.2$ \\
\hline $\mathrm{Cu}: \mathrm{C}_{\mathrm{a}}(\mu \mathrm{mol}: \mathrm{mol})$ & $3.8 \pm 0.5$ & $1.4 \pm 0.5$ & $1.3 \pm 0.4$ & $2.3 \pm 0.5$ & $2.0 \pm 0.8$ & $2.4 \pm 0.1$ \\
\hline
\end{tabular}

Manganese. The $\mathrm{Mn} \mathrm{CV} \mathrm{CV}^{-1}$ was the same for nitrateand ammonium-grown cells under the high and low $\mathrm{Fe}$ treatments (Table 2). However, under Fe-stress, nitrate-grown cells had significantly higher $\mathrm{Mn}$ levels per CV than ammonium-grown cells (Table 2). When normalized to $C$, these relationships were even more pronounced (Fig. 3B, Table 3).

Zinc. The $\mathrm{Zn} \mathrm{CV} \mathrm{CV}^{-1}$ was the same for nitrate- and ammonium-grown cells under the high Fe treatment (Table 2). Similarly, when normalized to C, ammonium- and nitrate-grown cells were not different under high Fe or under Fe-stressed conditions (Table 3)

Copper. The $\mathrm{Cu} \mathrm{CV} \mathrm{CV}^{-1}$ was not different between nitrate-and ammonium-grown cells under high Fe or under Fe-stress (Table 2). However, nitrate-grown cells had higher $\mathrm{Cu} \mathrm{CV}^{-1}$ values than ammonium-grown cells under the low Fe treatment (Table 2). The same relationships hold true when normalized to C (Fig. 3C, Table 3 ).

\section{Irradiance experiments}

\section{Growth rate}

The growth rates of both nitrate- and ammoniumgrown cells increased with irradiance (Fig. 4A). At the lowest irradiance level which supported growth (24 $\mu \mathrm{mol} \mathrm{m} \mathrm{m}^{-2} \mathrm{~s}^{-1}$ ), nitrate-grown cells had significantly higher growth rates than ammonium-grown cells (Fig. 4A). At all other irradiance levels the growth rates of nitrate- and ammonium-grown cells were not statistically different.

\section{Cell volume}

The CV of both nitrate- and ammonium-grown cells was larger under high (and growth saturating) ir- radiances than under low irradiances (Fig. 4B). Under the 2 lowest irradiance levels there was no significant difference in CV between nitrate- and ammoniumgrown cells (Fig. 4B). However, ammonium-grown cells were significantly larger than nitrate-grown cells at growth-saturating irradiances.

\section{Chlorophyll a}

Chl a $\mathrm{CV}^{-1}$ increased with decreasing irradiance, with the exception of the lowest irradiance level, where chl a CV ${ }^{-1}$ decreased (Fig. 4C). At 47 and $70 \mu \mathrm{E}$ $\mathrm{m}^{-2} \mathrm{~s}^{-1}$, the chl a $\mathrm{CV}^{-1}$ was significantly greater for nitrate-grown cells compared to ammonium-grown cells (Fig. 4C).

\section{DISCUSSION}

This was the first study to report basic physiological and multi-element metal composition parameters for an oceanic coccolithophore isolated from the NE subarctic Pacific. In addition, the effect of nitrogen source on the basic physiology of an oceanic coccolithophore has not previously been examined, nor the interactions that $\mathrm{Fe}$ or irradiance may have in conjunction with nitrogen source. Specific results from the experiments will first be discussed, followed by discussions pertaining to the ecological scenario at Stn P.

\section{Effect of $\mathrm{N}$ source under Fe-replete conditions}

Under the Fe-replete (100 nM) treatment in the Fe experiments, there appeared to be no physiological differences between nitrate- and ammonium-grown cells in any of the parameters that we measured. Other 

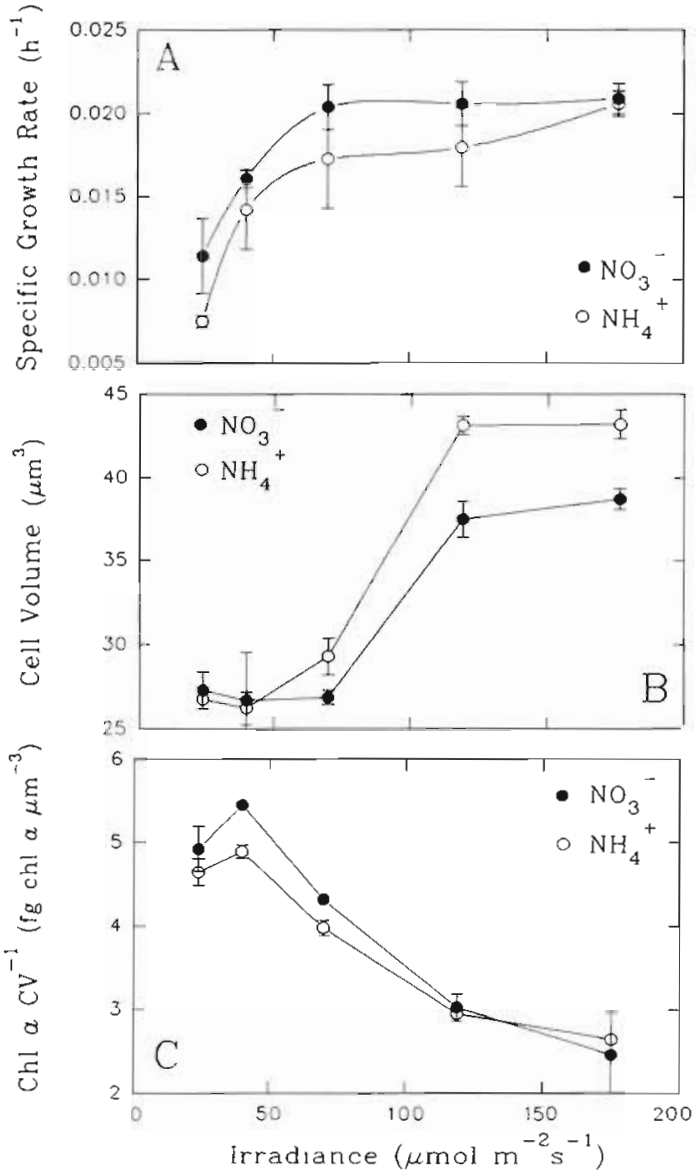

Fig. 4. Emiliania huxleyi. (A) Specific growth rate, (B) cell volume, and (C) chl a per $\mathrm{CV}$ for $\mathrm{NO}_{3}{ }^{-}$- and $\mathrm{NH}_{4}{ }^{+}$-grown cells vs irradiance. Error bars represent standard error $(n=3)$

researchers have previously found differences in growth rates between nitrate- and ammonium-grown cells under saturating conditions. Thompson et al. (1989), using a marine diatom (Thalassiosira pseudonana) under saturating light and Fe-replete conditions, found that the growth rates of ammonium-grown cells were significantly higher $(8 \%)$ than the growth rates of nitrate-grown cells. Similarly, Levasseur et al. (1993) found higher growth rates for ammonium-grown cells than for nitrate-grown cells of several species under the same conditions. However, an oceanic diatom isolated from the subarctic Pacific was found to have no difference in the growth rates of nitrate- and ammonium-grown cells under Fe-replete conditions (Muggli et al. in press). Despite the possible energetic advantages, higher growth on ammonium does not always occur.

Levasseur et al. (1993) also found that nitrate-grown cells had lower $\mathrm{N}$ quotas than ammonium-grown cells for the diatom Thalassiosira pseudonana under satu- rating light and Fe conditions. This may have been due to the lower energetic cost of ammonium transport and utilization compared to nitrate. In our Fe experiments, however, no such difference was observed under Fereplete conditions; nitrate-grown cells were able to maintain similar $\mathrm{N}$ quotas compared to ammoniumgrown cells. Thompson et al. (1989) found that nitrategrown cells had $21 \%$ lower C quotas than ammoniumgrown cells, and they attributed this to the possibility that competition for reductant may reduce the $\mathrm{C}$ quotas (and growth rate) of nitrate-grown cells. However, again, nitrate-grown cells of Emiliania huxleyi in the present study maintained the same $\mathrm{C}$ quotas, $\mathrm{CV}$, chlorophyll, and $\mathrm{N}$ levels per $\mathrm{CV}$ as ammonium-grown cells under Fe-replete conditions (Table 1, Fig. 2).

Similar to the physiological parameters, there was no different in the metal composition of nitrate- and ammonium-grown cells under Fe-replete conditions (Table 3). Despite the prediction that nitrate-grown cells should maintain higher Fe quotas than ammonium-grown cells under saturating conditions (Raven 1988), we did not find this in the Fe-replete cultures, even though the growth rates were similar. Sunda \& Huntsman (1995) also did not find a difference in $\mathrm{Fe}_{\text {int }}: \mathrm{C}$ ratios between nitrate- and ammonium-grown cultures of E. huxleyi (their isolate was from the Gulf of Mexico). This expected relationship was also absent in Fe-replete cultures of an oceanic diatom (Actinocyclus sp.) from the NE subarctic Pacific (Muggli et al. in press).

We can compare our Mn, Zn, and Cu quotas with the few studies that have reported these parameters previously. Ours is the first study, however, to measure multiple metals simultaneously on an oceanic coccolithophore. The range of $\mathrm{Mn}: \mathrm{C}_{\mathrm{t}}$ values that Emiliania huxleyi maintains under replete conditions is between 10 to $14 \mu \mathrm{mol} \mathrm{Mn:mol} \mathrm{C}$ (Fig. 4B, Table 3). The previously reported $\mathrm{Mn}: \mathrm{C}$ ratios are for 2 diatom species, both Thalassiosira sp., and range from 22 to $32 \mu \mathrm{mol}$ $\mathrm{Mn}: \mathrm{mol} \mathrm{C}$ under saturating conditions maximal for growth (Sunda 1988/1989). The oceanic diatom Actinocyclus sp. maintained a Mn:C ratio of $34 \mu \mathrm{mol}$ $\mathrm{Mn}$ :mol $\mathrm{C}$ for Fe-replete conditions (Muggli et al. in press). It appears, then, that $E$. huxleyi maintains a lower $\mathrm{Mn}: \mathrm{C}$ ratio than other previously reported species (although all diatoms), including one diatom from the subarctic Pacific. This is in agreement with the finding of Brand et al. (1983) that oceanic coccolithophores have a low requirement of $\mathrm{Mn}$ for growth relative to other phytoplankton.

The $\mathrm{Zn}: \mathrm{C}$ ratio maintained by Fe-replete cells of Emiliania huxleyi was ca $17 \mu \mathrm{mol} \mathrm{Zn}$ : mol C (Table 3). Previous reports of $\mathrm{Zn}: \mathrm{C}$ are from 3 diatom species (all Thalassiosira sp.) and 2 isolates of E. huxleyi ( 1 from the Sargasso Sea, 1 from the Gulf of Mexico) and range 
from 11 to 14 for the diatoms and as low as $1 \mu \mathrm{mol}$ $\mathrm{Zn}$ :mol C for the E. huxleyi isolates (Sunda \& Huntsman 1992). An oceanic diatom from the subarctic Pacific maintained a ratio of 3 to $7 \mu$ mol $\mathrm{Zn}$ :mol C under Fe-replete conditions (Muggli et al. in press). Our E. huxleyi from the NE subarctic Pacific appears to have a requirement for $\mathrm{Zn}$ that lies in the upper range of previously reported values, being at least double the requirement for the diatom from the same location.

There have been no recently published estimates of Cu:C ratios in phytoplankton. However, Price \& Morel (1994) report 2 studies on Chlorella sp. for which the estimated values were 0.8 and $9 \mu \mathrm{mol} \mathrm{Cu}: \mathrm{mol} \mathrm{C}$ for $90 \%$ of maximum growth (Walker 1953, Manahan \& Smith 1973). Our values for E. huxleyi are between 1 and $2 \mu \mathrm{mol} \mathrm{Cu}: \mathrm{mol} \mathrm{C}_{1}$, which lies within the range of previously reported values.

The intracellular Fe:C ratios as a function of growth for this isolate of Emiliania huxleyi will be reported in detail elsewhere (Muggli \& Harrison unpubl.).

\section{Effect of $\mathbf{N}$ source under Fe-stressed conditions}

Theoretically, the competition for reductant should become more severe under Fe-stressed conditions, and therefore ammonium-grown cells should be able to maintain even higher growth rates, $N$ quotas and $C$ quotas than nitrate-grown cells. Rueter \& Ades (1987) examined the possibility of Fe-stressed cells being limited by reducing power using cultures of the green alga Scenedesmus quadricauda. They found that under Fe-stress, ammonium-grown cultures had higher $\mathrm{C}$ fixation rates than nitrate-grown cells under a range of irradiance levels (ca 20 to $180 \mu \mathrm{mol} \mathrm{m} \mathrm{m}^{-2} \mathrm{~s}^{-1}$ ). This observation along with other information allowed them to conclude that Fe-stressed cells can exhibit the same response as energy-limited cells (Rueter \& Ades 1987). However, in our $\mathrm{Fe}$ experiments, ammoniumgrown cells of Emiliania huxleyi did not show signs of any energy advantage over nitrate-grown cells under Fe-stress. For example, nitrate-grown cells maintained the same or greater chlorophyll, $N$ and $C$ levels as ammonium-grown cells under Fe-stressed conditions (Fig. 2, Table 1). This was primarily the result of the nitrate-grown cells substantially reducing their CVs under Fe-stress (Fig. 1).

\section{Growth (Fe-stress vs low light)}

Since Fe-stress could lead to energy-limited cells similar to light-limited cells, it is interesting to compare the effects of low irradiance levels on nitrate- and ammonium-grown cells (Fig. 4). Under low irradiance levels where the competition for reductant is most severe, nitrate-grown cells of Emiliania huxleyi grew significantly faster than ammonium-grown cells, in contrast to what would be theoretically expected (Fig. 4A). In the Fe experiments, before the cessation of cell division by Fe-stress was achieved, nitrate-grown cells were also growing faster than ammonium-grown cells (data not shown), as was the case for the $0.8 \mathrm{nM}$ Fe treatment. The smaller $\mathrm{CV}$ of nitrate-grown cells compared to ammonium-grown cells could have partially accounted for the faster division rate (lower requirement of $\mathrm{C}, \mathrm{N}$, metals, etc.), but why this was also found in the irradiance experiments when the CVs were identical under low light is puzzling.

\section{Cell volume (Fe-stress vs low light)}

The most contrasting finding between the low irradiance cultures and the Fe-stressed cultures was that no difference in CV was found between nitrate- and ammonium-grown cells in the low irradiance cultures, whereas there was a large difference in $\mathrm{CV}$ between nitrate- and ammonium-grown cultures under $\mathrm{Fe}$ stress (Figs. $2 \& 4 \mathrm{~B}$ ). The decrease in $\mathrm{CV}$ of nitrategrown cells and not ammonium-grown cells in response to severe Fe-stress in the Fe experiments indicates that somehow the nitrate-grown cells were more severely affected by Fe-stress than the ammonium-grown cells, and that more than just photosynthetically derived products and energy may have been the cause of this change. Fe-stress will also affect non-photosynthetic energy deriving processes such as respiration, as well as possibly hindering the synthesis of nitrate and nitrite reductase (although a difference on the scale of atoms of Fe would probably not cause a differencel. Somehow the ammoniumgrown cells under Fe-stress did not require a reduction in $\mathrm{CV}$ to meet their metabolic needs, whereas the nitrate-grown cells acclimated to $\mathrm{Fe}$ stress by reducing their CV.

A decrease in CV supports the prediction by Hudson \& Morel (1990) that oceanic phytoplankton cannot increase their Fe transport kinetics, and consequently their only means of acclimation to Fe-stressed conditions is a reduction in Fe-requirement or a reduction in cell size. This reduction in CV in response to Fe-stress has also been found to occur in a dinoflagellate (Doucette \& Harrison 1990), but nitrate was the only nitrogen source used. The only other study to-date that has examined the effects of both nitrate and ammonium on CV under Fe-stress is for an oceanic diatom, and no difference in $\mathrm{CV}$ was found under Fe-stress between nitrate- and ammonium-grown cells (Muggli et al. in press). 
Chlorophyll a quotas (Fe-stress vs low light)

The difference in chlorophyll quotas between nitrate- and ammonium-grown cultures in the irradiance experiments mimics the results obtained in the $\mathrm{Fe}$ experiments. Under 2 of the sub-saturating irradiance levels $\left(45\right.$ and $70 \mu \mathrm{mol} \mathrm{m} \mathrm{m}^{-2} \mathrm{~s}^{-1}$ ), nitrate-grown cells maintained higher chlorophyll per $\mathrm{CV}$ ratios than ammonium-grown cells, similar to that which was found under Fe-stress (Figs. 4C \& 2A). Under low irradiance, where the competition for reductant is the most crucial, it is surprising to observe nitrate-grown cells maintaining higher chlorophyll levels than ammonium-grown cells. However, since nitrate-grown cells would need more reductant to transport and utilize their $N$ source, they may require more chlorophyll than ammonium-grown cells to meet these needs. Thompson et al. (1989) came to the conclusion that nitrategrown cells may be more efficient in the production of reductant than ammonium-grown cells, and nitrategrown cells could achieve this by being more efficient in light absorption or by improving their quantum yield in some other way. One of these ways may be to increase their chlorophyll levels. The same arguments can be applied to the fact that nitrate-grown cells of Emiliania huxleyi under Fe-stress had higher levels of chlorophyll than ammonium-grown cells. Apparently the expected added strain of Fe limitation on nitrategrown cells does not severely affect the cell's ability to synthesize chlorophyll relative to ammonium-grown cells.

The generally expected observation of decreased chlorophyll quotas under Fe-stress that has been found in other studies (Glover 1977. Doucette \& Harrison 1990, Greene et al. 1991, 1992, Rueter \& Unsworth 1991) was not evident in Emiliania huxleyi (Fig. 2A, Table 1). Despite a greater than 10 times reduction in the cellular Fe quota, Fe-stressed cells maintained relatively constant $\mathrm{C}$ :chlorophyll ratios (Table 1 ). This oceanic coccolithophore appears truly unique in this regard. In contrast, an oceanic diatom (Actinocyclus sp.) from the NE subarctic Pacific exhibited significant decreases in chlorophyll levels under Fe-stress (Muggli et al. in press). E. huxleyi must have some unique metabolic characteristics which allow it to maintain chlorophyll synthesis under severe Fe-stress (when Fe was limiting cell division completely). This may be one of the ways in which this organism survives at Stn P continually.

\section{Metal quotas}

The only difference in metal quotas between nitrate- and ammonium-grown cells when cell divi- sion had just ceased due to Fe-stress was that nitrategrown cells had significantly higher $\mathrm{Mn}$ : C ratios than ammonium-grown cells (Table 3 ). Both nitrate- and ammonium-grown cultures in the Fe-stressed treatment were exposed to greater $\mathrm{Mn}$ levels than in the other 2 Fe treatments due to the addition of $\mathrm{Mn}$ in the process of inducing Fe-stress. However, ammoniumgrown cells did not increase their cellular $\mathrm{Mn}$ levels, whereas nitrate-grown cells did (Fig. 4B, Tables 2 \& 3). One factor that could possibly explain this, in part, was that the nitrate-grown cells decreased their CVs whereas the ammonium-grown cells did not. This reduction in CV would increase the surface area to volume ratio, possibly resulting in more surface uptake sites per volume than in ammonium-grown cells. The phenomenon of increased cellular $\mathrm{Mn}$ levels under Fe-stress for nitrate-grown cells has been found previously; Fe-limited cells of Thalassiosira weissflogii grown on nitrate had higher $\mathrm{Mn}$ quotas than Fe-replete cells at fixed concentration of free Mn ion (Harrison \& Morel 1986). In addition, an oceanic diatom from the subarctic Pacific also exhibited this response (Muggli et al. in press). In the present study, the nitrate-grown cells under Fe-stress contained more $\mathrm{Mn}$ and chlorophyll per carbon than ammonium-grown cells, indicating that photosystem II may somehow be more active in Fe-stressed nitrate-grown cells than Fe-stressed ammoniumgrown cells.

\section{Ecological relevance}

\section{Comparison of Emiliania huxleyi isolates from different locales}

It is known that genetic variation is prevalent among Emiliania huxleyi isolates from different locations (Brand 1982, van Bleijswijk et al. 1991, Young \& Wesbrook 1991), and this may explain some of the variation in physiological characteristics observed between isolates from different areas of the ocean. Growth rate can be an indicator of the overall physiology of a cell, and it is a parameter frequently measured in other studies. Although there are differences in culturing conditions, our E. huxleyi isolate from the subarctic Pacific had a much lower maximal growth rate than other reported isolates. Paasche \& Klaveness (1970) found that the coccolith-forming cells of E. huxleyi from Oslo fjord, Norway had a maximum growth rate of 1.68 doublings $\mathrm{d}^{-t}\left(21^{\circ} \mathrm{C}\right.$, continuous light $)$. Similarly, Brand (1982) examined 73 clones of $E$. huxleyi isolates from the Sargasso Sea and the Gulf of Maine and found growth rates ranging from 1.5 to 1.7 divisions $\mathrm{d}^{-1}\left(20^{\circ} \mathrm{C}, 14 \mathrm{~h}\right.$ light: $10 \mathrm{~h}$ dark cycle). In contrast, our isolate of $E$. hux- 
leyi from Stn $\mathrm{P}$ grows maximally at ca 0.6 doublings $\mathrm{d}^{-1}$ at $16^{\circ} \mathrm{C}$ with a $14 \mathrm{~h}$ light: $10 \mathrm{~h}$ dark regime. This is also the maximal growth rate achieved by this isolate when grown on artificial seawater under continuous illumination (Lecourt et al. in press). Since all other isolates reported here are from the Atlantic Ocean while ours is from the Pacific, it would be expected that genetic differences are present. However, our isolate is the only one from an HNLC area Brand (1994) hypothesized that some coccolithophores in oligotrophic areas may exhibit extreme $K$-selection; that is, grow extremely well at low nutrient concentrations and not grow any faster at higher nutrient concentrations.

\section{The subarctic Pacific}

Since dissolved $\mathrm{Fe}$ concentrations in the surface waters of the NE subarctic Pacific have been measured to be 0.05 to $0.4 \mathrm{nmol} \mathrm{kg}{ }^{-1}$ seawater (Martin \& Gordon 1988, P. Boyd et al. unpubl., I. Kudo unpubl. data), our experimental conditions of 'low $\mathrm{Fe}^{\prime}$ ' total

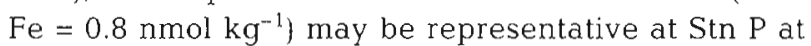
some times. The external Fe concentration in the Festressed culture flasks in which cell division had actually ceased was likely extremely small, as this organism has been found previously to be difficult to Fe-limit in the laboratory (Brand et al. 1983). However, in all of the present experiments (as well as in all other previously reported trace metal-phytoplankton studies), EDTA was present in the culture medium (10 $\mu \mathrm{M}$ EDTA in our case), making a direct comparison with entirely natural seawater difficult. Not only does EDTA affect the speciation of trace metals, it may also interfere with naturally produced organic compounds that may serve as biological aids for metal acquisition. Results of an experiment conducted with both Emiliania huxleyi and an oceanic diatom in natural Stn P water without EDTA present will be reported elsewhere (Muggli \& Harrison unpubl.). For the purposed of this study, then, we will focus our discussion on the possible effects of nitrogen source.

Under the experimental low Fe conditions $10.8 \mathrm{nmol}$ $\mathrm{kg}^{-1}$ ), ammonium-grown cells did not appear to have a physiological advantage over nitrate-grown cells. In fact, nitrate-grown cells had significantly higher growth rates than ammonium-grown cells under these conditions (Table 1). This would indicate that if fast cell division is ecologically favored and cells would acclimate to this, Emiliania huxleyi may be utilizing nitrate in situ to meet its nitrogen requirements. ${ }^{15} \mathrm{~N}$ experiments conducted at Stn $\mathrm{P}$ have indicated that the small size fraction $(<5.0 \mu \mathrm{m})$ is utilizing nitrate to some extent $(30$ to $50 \%$ of nitrogen require- ment; D. Varela unpubl. data). Similarly, Price et al. (1994) in the equatorial Pacific (another HNLC region) found that nitrate was being utilized by the indigenous small phytoplankton. Attributing nitrate uptake to single species in the field is difficult, as mixed assemblages are always present. Furthermore, species assemblages can vary dramatically at a single locale, let alone in different regions of the ocean. However, these field data would indicate that there is a possibility that E. huxleyi, and possibly other small prymnesiophytes like them, are indeed utilizing nitrate in situ. The irradiance experiments also support the notion that $E$. huxleyi is utilizing nitrate in situ, as faster growth was found for nitrate-grown cells under low light, and ammonium-grown cells never grew faster than nitrate-grown cells (Fig. 4A).

Hence, results from our experiments would indicate that under normal, low Fe conditions in the subarctic Pacific, Emiliania huxleyi is probably utilizing nitrate as its primary $\mathrm{N}$ source. In the event of $\mathrm{Fe}$ addition to the system (via atmospheric deposition), our data does not indicate that one $\mathrm{N}$ source over the other is more beneficial to this organism. Assessing which $\mathrm{N}$ source is actually taken up under ecologically relevant concentrations in the laboratory is the next step in understanding the ecophysiology of this species at Stn P. Wells et al. (1995) point out the complete absence of laboratory studies on organisms from the field locations in question. Care must especially be taken when working with $E$. huxleyi, as there is much genetic variation between isolates (Brand 1982), and the origin of the isolate should be clearly identified in all reports. In addition, if truly ecological questions are to be asked, the culture conditions in the laboratory need to be carefully considered (e.g. omitting artificial chelators; see Muggli \& Harrison unpubl.). Physiological laboratory studies on organisms from HNLC regions need to be conducted if we are to truly understand the ecology of these systems and how the individual organisms present would respond to perturbations to the system.

Acknowledgements. We thank the UBC JGOFS team for providing Stn P water, E. Simons for sharing her knowledge of species isolation, and Dr K. Orians and students for the use of their clean room and equipment for the dissolved iron measurements. Two anonymous reviewers helped improve the manuscript. Financial support was provided by the Natural Sciences and Engineering Research Council of Canada (NSERC). D.L.M. received support from a UBC University Graduate Fellowship.

\section{LITERATURE CITED}

Booth BC (1988) Size classes and major taxonomic groups of phytoplankton at two locations in the subarctic Pacific in May and August 1984. Mar Biol 97:275-286 
Booth BC, Lewin J, Norris RE (1982) Nanoplankton species predominate in the subarctic Pacific in May and June 1978. Deep Sea Res 29:185-200

Brand LE (1982) Genetic variability and spatial patterns of genetic differentiation in the reproductive rates of the marine coccolithophores Emiliania huxleyi and Gephyrocapsa oceanica. Limnol Oceanogr 27:236-245

Brand LE (1994) Physiological ecology of marine coccolithophores. In: Winter A, Siesser WG (eds) Coccolithophores. Cambridge University Press, Cambridge, p 39-49

Brand LE, Sunda WG, Guillard RRL (1983) Limitation of marine phytoplankton reproductive rates by zinc, manganese, and iron. Limnol Oceanogr 28:1182-1198

Bruland KW, Donat JR, Hutchins DA (1991) Interactive influences of bioactive trace metals on biological production in oceanic waters. Limnol Oceanogr 36:1555-1577

Doucette GJ, Harrison PJ (1990) Some effects of iron and nitrogen stress on the red tide dinoflagellate Gymnodinium sanguineum. Mar Ecol Prog Ser 62:293-306

Falkowski PG (1975) Nitrate uptake in marine phytoplankton (nitrate-chloride)-activated ATP from Skeletonema costatum (Bacillariophyceae). J Phycol 11:323-326

Flynn KJ (1990) Coccolithophorids, nutrients and the greenhouse effect. Chem Ecol 4:109-116

Glover H (1977) Effects of iron deficiency on Isochrysis galbana (Chrysophyceae) and Phaeodactylum tricornutum (Bacillariophyceae). J Phycol 13:208-212

Goodwin TW, Mercer El (1983) Introduction to plant biochemistry. Pergamon Press Inc, Oxford

Greene RM, Geider RJ, Falkowski PG (1991) Effect of iron limitation on photosynthesis in a marine diatom. Limnol Oceanogr 36:1772-1782

Greene RM, Geider RJ, Kolber Z, Falkowski PG (1992) Ironinduced changes in light harvesting and photochemical energy conversion processes in eukaryotic marine algae. Plant Physiol 100:565-575

Harrison GI, Morel FMM (1986) Response of the marine diatom Thalassiosira weissflogii to iron stress. Limnol Oceanogr 31:989-997

Holligan PM, Fernandez E, Aiken J, Balch WM, Boyd P, Burkill PH, Finch M, Groom SB, Malin G, Muller K, Purdie $\mathrm{DA}$, Robinson $\mathrm{C}$, Trees $\mathrm{CC}$, Turner $\mathrm{SM}$, van der Wal $\mathrm{P}$ (1993) A biogeochemical study of the coccolithophore, Emiliania huxleyi, in the north Atlantic. Global biogeochem Cycles 7:879-900

Honjo S, Okada H (1974) Community structure of coccolithophores in the photic layer of the mid-Pacific. Micropaleontology 20:209-230

Hudson RJM, Morel FMM (1989) Distinguishing between extra- and intracellular iron in marine phytoplankton Limnol Oceanogr 34:1113-1120

Hudson RJM, Morel FMM (1990) Iron transport in marine phyloplankton: kinetics of cellular and medium coordination reactions. Limnol Oceanogr 35:1002-1020

Keller MD, Bellows WK, Guillard RRL (1988) Microwave treatment for sterilization of phytoplankton culture media $\mathrm{J}$ exp mar Biol Ecol 117:279-283

Keller MD, Bellows WK, Guillard RRL (1989) Dimethyl sulphide production in marine phytoplankton. In: Saltzman ES, Cooper WJ (eds) Biogenıc sulphur in the marine environment. Am Chem Soc Symp Ser, Vol 393. American Chemical Society, Washington, DC, p 167-182

Lecourt M. Muggli DL, Harrison PJ (1995) Comparison of growth and sinking rates of non-coccolith and coccolith forming strains of Emiliania huxleyi (Prymnesiophyceae) grown under different irradiance and nutrogen sources. J Phycol (in press)
Levasseur MAA, Thompson PA, Harrison PJ (1993) Physiological acclimation of marine phytoplankton to different nitrogen sources. J Phycol 29:587-595

Manahan SE, Smith MJ (1973) Copper micronutrient requirement for algae. Environ Sci Technol 7:829-833

Martin JH, Gordon RM (1988) Northeast Pacific iron distributions in relation to phytoplankton productivity. Deep Sea Res 35:267-285

Martin JH, Gordon RM, Fitzwater SE, Broenkow WW (1989) VERTEX: phytoplankton/iron studies in the Gulf of Alaska. Deep Sea Res 36:649-680

Miller CB, Frost BW, Wheeler PA, Landry MR, Welschmeyer N, Powell TM (1991) Ecological dynamics in the subarctic Pacific, a possibly iron limited system. Limnol Oceanogr 36:1600-1615

Morel FMM, Hudson RJM, Price NM (1991) Limitation of productivity by trace metals in the sea. Limnol Oceanogr 36 : $1742-1755$

Muggli DL, Lecourt M. Harrison PJ (in press) Effects of iron and nitrogen on the sinking rate, physiology and metal composition of an oceanic diatom from the subarctic Pacific. Mar Ecol Prog Ser

Paasche E, Klaveness D (1970) A physiological comparison of coccolith-forming and naked cells of Coccolithus huxleyi. Arch Mikrobiol 73:143-152

Parsons TR, Maita Y, Lalli CM (1984) A manual of chemical and biological methods for seawater analysis. Pergamon Press, New York

Price NM, Ahner BA, Morel FMM (1994) The equatorial Pacific Ocean: grazer-controlled phytoplankton populations in an iron-limited ecosystem. Limnol Oceanogr 39:520-534

Price NM, Anderson LF, Morel FMM (1991) Iron and nitrogen nutrition of equatorial Pacific plankton. Deep Sea Res 38: $1361-1378$

Price NM, Harrison GI, Hering JG, Hudson RJ, Nivel MV, Palenic B, Morel FMM (1988/1989) Preparation and chemistry of the artificial algal culturing medium Aquil. Biol Oceanogr 6:443-461

Price NM, Morel FMM (1994) Trace metal nutrition and toxicity in phytoplankton. In: Algae and water pollution. Adv Limnol 42:79-97

Raven JA (1988) The iron and molybdenum use efficiencies of plant growth with different energy, carbon and nitrogen sources. New Phytol 109:279-287

Rueter JG, Ades ER (1987) The role of iron nutrition in photosynthesis and nitrogen assimilation in Scenedesmus quadricauda (Chlorophyceae). J Phycol 23:452-457

Rueter JG, Unsworth NL (1991) Response of marine Synechococcus (Cyanophyceae) cultures to iron nutrition. J Phycol 27:173-178

Sandmann G (1985) Consequences of iron deficiency on photosynthetic and respiratory electron transport in bluegreen algae. Photosynth Res 6:261-271

Sandmann G, Boger P (1983) The enzymological function of heary metals and their role in electron transfer processes of plants. In: Lauchli A, Bielesky RK (eds) Encyclopedia of plant physiology, New Series, Vol 15, Inorganic plant nutrition. Springer, Berlin, p 63-96

Spiller SC, Castelfranco AM, Castelfranco PA (1982) Effects of iron and oxygen on chlorophyll biosynthesis. I. In vivo observations on iron and oxygen-deficient plants. Plant Physiol 69:107-111

Sunda WG (1988/1989) Trace metal interactions with marine phytoplankton. Biol Oceanogr 6:411-442

Sunda WG, Huntsman SA (1992) Feedback interactions between zinc and phytoplankton in seawater. Limnol Oceanogr 37:25-40 
Sunda WG, Huntsman SA (1995) Iron uptake and growth limitation in oceanic and coastal phytoplankton. Mar Chem 50:189-206

Sunda WG, Swift DG, Huntsman SA (1991) Low iron requirement for growth in oceanic phytoplankton. Nature 351 $55-57$

Taylor FJR, Waters RE (1982) Spring phytoplankton in the subarctic North Pacific Ocean. Mar Biol 67:323-335

Terry $N(1980)$ Limiting factors in photosynthesis I. Use of iron stress to control photochemical capacity in vivo. Plant Physiol 65:114-120

Terry N (1983) Limiting factors in photosynthesis IV lron stress-mediated changes in light-harvesting and electron transport capacity and its effects on photosynthesis in vivo. Plant Physiol 71:855-860

Thompson PA, Levasseur ME, Harrison PJ (1989) Light-limited growth on ammonium vs. nitrate: what is the advantage for marine phytoplankton? Limnol Oceanogr 34 $1014-1024$

Turpin DH, Bruce D (1990) Regulation of photosynthetic light

This article was presented by K. Banse, Seattle, Washington, USA harvesting by nitrogen assimilation in the green alga Selenastrum minutum. FEBS Lett 263:99-103

van Bleijswijk $J$, van der Wal $P$, Kempers $R$, Veldhuis $M$, Young JR, Muyzer $G$, deVrind-deJong $E$, Westbroek $P$ (1991) Distribution of two types of Emiliania huxleyi (Prymnesiophyceae) in the northeast Atlantic region as determined by immunofluorescence and coccolith morphology. J Phycol 27:566-570

Walker JB (1953) Inorganic micronutrient requirements of Chlorella. I. Requirements for calcium (or strontium), copper and molybdenum. Archs Biochem Biophys 53:1-8

Wells ML, Price NM, Bruland KW (1995) Iron chemistry in seawater and its relationship to phytoplankton: a workshop report. Mar Chem 48:157-182

Yang L (1993) Determination of dissolved trace metals in the western North Pacific. MSc thesis, University of British Columbia, Vancouver

Young JR, Westbroek P (1991) Genotypic variation in the coccolithophorid species Emiliania huxleyi. Mar Micropaleontol 18:5-23

Manuscript first received: March 31, 1995

Revised version accepted: October 2, 1995 